\title{
Pueblo de Dios 1971-72
}

por SANTIAGO LORENTE

Intentar hacer balance de la Iglesia acerca de un año que ya pasó y, mirando al que comienza, es tarea ciertamente arriesgada. $Y$ esto, porque mientras la inteligencia humana disponga de un entendimiento limitado-y esto sucederá siempre-, estará obligada a ver la realidad sólo desde perspectivas parciales-aunque no por ello falsas-. Plenamente consciente de esta realidad se ha escrito el presente artículo.

En primer lugar, hay que aclarar que todo juicio sobre la Iglesia debe arrancar de la idea de lo que es Iglesia. Y si la lglesia es; desde el concepto teológico más maduro, ante todo, pueblo de Dios, todo juicio sobre la Iglesia habrá de versar casi exclusivamente sobre este pueblo de Dios.

Esta óptica me parece fundamental, y por eso, más de un lector echará de menos en este artículo una atención más detenida a problemas de obispos, sacerdotes, religiosos y religiosas o movimientos especializados dentro de la Iglesia.

El año 1971, en España ha sido uno más en que el pueblo de Dios ha seguido considerando como actividad primaria de su vida cristiana la práctica cultual. No se afirma con esto que la gente practique. Se afirma, en cambio, que la vida de la lglesia es concebida casi exclusivamente en primer lugar, como la actividad cultual que se desarrolla físicamente dentro de los muros del templo, y en segundo lugar, como las personas que desarrollan tal actividad y en tal sitio. La proyección dinámica de la vida cristiana a otros ámbitos de la existencia deja-hoy por hoy-mucho que desear. La vida familiar como "culto cristiano"; el trabajo esforzado y honrado como "culto cristiano"; incluso el merecido descanso y espar- 
cimiento como "culto cristiano"; he aqui al menos unos aspectos fundamentales de vida auténticamente cristiana que no parecen estar intimamente conectados con la idea y la realización de una vida integralmente eclesial.

Las prácticas cultuales han descendido asimismo cuantitativamente. Esto no implica, como es lógico, un juicio a nivel cualitativo. El pueblo sigue manteniendo aquellos sacramentos que se reciben alguna vez en la vida: bautismo, confirmación, primera comunión, matrimonio y, aunque menos, unción de los enfermos. Sería demasiado simplista atribuirlo exclusivamente a una mera fuerza de tradición o práctica floklórica. El descenso, en cambio, se observa cada vez más en los sacramentos de práctica más frecuente, como es la eucaristía dominical $y$, sobre todo, la confesión.

Lo que se practica o no se practica, y el modo de hacerlo en definitiva, se debe a lo que se cree o no se cree. El nivel y el contenido de creencias es, pues, la base. La Iglesia es la comunidad de los creyentes.

Los dogmas más intangibles son los que aparecen más en tela de juicio porque, en principio, son los más difíciles de compaginar con la razón y la evidencia aparente. El caso típico es la resurrección de la persona a una vida trascendente. Este dogma cuenta con un porcentaje muy bajo de creyentes entre el normal pueblo de Dios, y todavía más bajo entre las personas de escasa cultura. Esta conclusión es común a muchos estudios realizados.

En el campo de la moral, el pueblo de Dios sigue manteniendo muy profundamente el instinto de lo bueno, igual que lo sigue manteniendo el pueblo que no es explícitamente cristiano (o bautizado). Con esto pretendo afirmar que la humanidad es buena, más buena de lo que en general a veces pensamos. Pero lo que también pretendo afirmar es que la moral cristiana adolece de una falta de relación directa y motivación en Cristo, en su persona y en su ejemplo. En la moral cristiana hay además un énfasis despropor. cionado en el campo del 6. Mandamiento, énfasis hacia lo funcional de los órganos sexuales y, por el contrario, falta de hincapié en la dinámica madura de las relaciones interpersonales.

Un campo virgen de la moral cristiana sigue siendo el $7 .^{\circ}$ Mandamiento. No hay ni una reflexión teórica madura y actualizada al mundo complejo de hoy, ni-consecuentemente-una práctica desinteresada de las exigencias que provienen de la idea tan rica de la justicia como fruto del amor cristiano. 
En resumen, sólo una élite minúscula sigue el ritmo vital de la Iglesia. De esta élite, una parte lo hace y se siente cada vez más desconcertada por los "cambios"; y otra parte lo hace para interesarse cada vez más en la comunidad de los creyentes, y para ser ella misma "agente de cambio". Esta última minoría actúa cada vez más al margen de la institución eclesial; y el fenómeno parece irreversible.

Pero la gran mayoría de los cristianos han estado ausentes, y por eso no puedo estar de acuerdo con quienes piensan que el pueblo de Dios ha estado en 1971 a la expectativa. Al contrario, la Iglesia "sociológica" está dando claras muestras de ausentarse, de desintegrarse. En definitiva, de interesar cada vez menos.

A nivel de "responsables" de la Iglesia como institución visible, es decir, excluyendo a la gran masa del pueblo de Dios. el juicio sobre 1971 es muy distinto.

En primer lugar, la Asamblea Conjunta ha hecho noticia y ha sido signo. Noticia porque los periódicos tanto nacionales como extranjeros se han hecho profurido eco de ella. Y, además, se ha visto la enorme capacidad de mentir que tiene más de un periódico nacional que intentó boicotearla ante la opinión pública. $Y$ ha sido signo para los que quieren y anhelan un sacerdocio menos preocupado de sus derechos y privilegios civiles y políticos y más puramente preocupado por una misión de buena voluntad y de transmisión del mensaje cristiano. Lo triste es que muchos lo hayan entendido al contrario.

Sin embargo, la Asamblea Conjunta ha producido el mejor fruto de su ideal eclesial: reunir a miles de grupos de sacerdotes por todo to largo y ancho de España durante más de un año en reflexión comunitaria, y reunir durante una semana a Obispos y sacerdotes, sentados en las mismas sillas del Seminario. Esto es hacer Iglesia, $y$ esto es el fruto que no es noticia y que por eso no se ha dicho en los periódicos.

Más pernicioso y desorientador para la Iglesia que la introducción de sectas protestantes por los hogares españoles ha sido la división en el seno de sus responsables. División en el episcopado: si la Asamblea Conjunta descubrió algo en este sentido es que el cuerpo episcopal no es ciertamente monocolor. División en el clero: hecho constatable sin recurrir a la Asamblea Conjunta; basta con asistir a los sermones de las misas dominicales por distintas parroquias. División entre ciertos grupos eclesiales, algunos de 


\section{S. LORENTE}

ellos con el influjo que les proporciona el respaldo económico y político. Sólo Dios dirá-y la historia-si es posible y lícito conducir el vehículo de la Iglesia con el freno y la marcha atrás metidos.

De todas maneras, los hechos sueltos que una minoría cacarea son indicativos de lo mucho profundamente positivo que en el seno de la mayoría silenciosa está ocurriendo. Las declaraciones de Monseñor Cantero implican más bien que hay casi todo un episcopado más o menos dispuesto a seguir el camino de lo sencillo y humilde. Las huelgas de los estudiantes de teología implican que balbuceantemente la mayoría busca una teología meinos profesionalizada y más vitalmente actualizada. Los grupos poderosos interesados en desdibujar nuevas imágenes de la Iglesia están implicando-con su campaña sorda de destrucción-que realmente empieza a apuntar y a ser realidad esta nueva imagen.

Las revistas de ultraderechas, para su distribución masiva, necesitan de pingües ayudas económicas, y ello está diciendo a voces que ya no interesan al público; y el silencio de la prensa sobre los puntos más hondos de la teología del sacerdocio expuesta en la Asamblea Conjunta indica que hay un mayor consensus entre los sacerdotes... a pesar de todo.

De todo esto hay que concluir que una cosa es hacer balance de un año de Iglesia, y otra cosa muy distinta es hacer un comentario crítico de las noticias sobre las más destacadas élites de la Iglesia. Lo segundo sólo tiene importancia en cuanto es eco del común sentir del pueblo de Dios en general, pues él es la Iglesia. Va apa. reciendo claro que el cristianismo profundo vivido no podrá ser un fenómeno de masas. $Y$ va también apuntando la realidad no de una Iglesia identificada con el poder (aunque sea éste de orden sólo moral) sino con el servicio humilde a una humanidad que quiere ser salvada en Cristo. 